\title{
New Fossil Collection of Hippohyus sivalensis (Artiodactyla: Suidae: Suinae) from Late Miocene to Pliocene of Siwaliks of Pakistan
}

\author{
Sadaf Aslam ${ }^{1 *}$, Abdul Majid Khan' ${ }^{1}$ and Muhammad Akhtar ${ }^{2}$ \\ ${ }^{1}$ Department of Zoology, University of the Punjab, Quaid-e-Azam Campus, Lahore \\ ${ }^{2}$ Department of Zoology, Minhaj University, Lahore.
}

\begin{abstract}
A B S T R A C T
The fossil remains of Hippohyus (Artiodactyla, Mammalia) from the Late Miocene/Pliocene of Middle and Upper Siwaliks are described. Hippohyus sivalensis is a common suid of late Miocene to Pliocene rocks of Tatrot/Hasnot area of Pakistan. The molar resemblance with equids indicates their grazing feeding habits. This species migrated to Potwar land when grasslands became established. It has typical suine characters with hypsodont dentition and complex infolding of enamel surfaces. The described material consists of isolated molars. This discovery will provide a new insight to understand the diversity and geographic distribution of Siwalik Suids.
\end{abstract}

\begin{tabular}{l} 
Article Information \\
Received 06 February 2020 \\
Revised 29 October 2020 \\
Accepted 10 November 2020 \\
Available online 28 June 2021 \\
Authors' Contribution \\
\hline SA is a principal author who conduct- \\
ed the research. AMK provided the \\
lab and suggestions for article and MA \\
provided the samples. \\
Key words \\
\hline Suid, Suinae, Late miocene, Pliocene, \\
Siwaliks, Pakistan
\end{tabular}

\section{INTRODUCTION}

$\mathrm{S}$ iwaliks are freshwater Neogene deposits of Himalayan foothills that extend from Pakistan to Bhutan passing through India and Nepal. It has three main divisions, Lower, Middle and Upper Siwaliks. Lower Siwaliks include Kamlial and Chinji formations. Middle Siwaliks include Nagri and Dhok Pathan formations. Upper Siwaliks include Tatrot, Pinjor and Boulder Conglomerate formations (Medlicot, 1864). The lower contact of Upper Siwaliks is not conformable with Dhok Pathan Formation and the upper contact ends in boulder bed with angular conformity. The Boulder Conglomerate Stage is defined by coarse and conglomeratic depositions that show the end of the Upper Siwalik series.

Suids are conspicuous elements from MiocenePliocene rocks of Siwaliks (Pilgrim, 1926; Matthew, 1929; Lewis, 1934; Colbert, 1935; Pickford, 1993). Suids belong to the family Suidae of order Artiodactyla, and include living members of that family that are similar to the ancestral form. Extinct fossilized species of suids contribute much in mammalian evolutionary studies as some provide a linkage through Anthracotheres to Cetacea (Sarwar et al., 2016). Hippohyus belongs to subfamily Suinae.

The specimens described here have been collected from different localities of Late Miocene to Pliocene of

\footnotetext{
* Corresponding author: sadaf.hons@pu.edu.pk 0030-9923/2021/0005-1677 \$9.00/0

Copyright 2021 Zoological Society of Pakistan
}

Upper Siwaliks of the Kotal Kund, Tatrot, Hasnot and Pinjor areas.

Hasnot (Lat. 32 $49^{\prime} 27.89$ N, Long. $7^{\circ} 07^{\prime} 52.68$ E) is situated about $35 \mathrm{~km}$ west of Jhelum city in Potwar Plateau, Punjab, Pakistan. Deposits are mainly comprised of freshwater sedimentary rocks of Neogene age. This area was deposited at 5.3-3.5Ma (Late Miocene-Early Pliocene). Various suid fossils of the Dhok Pathan formation have been explored from Hasnot (Batool et al., 2015).

Lithologically, the Pinjor Formation is characterized by the alternation of brown and pink mudstones and greygreen sandstones. Mudstones are dull, concretionary and of brown pink in color. Sandstones are medium to coarse grained, soft to medium hard, current bedded and pebbly. Dips are low and beds can be traced along the strike and dip slopes form excellent sites for fossil collection (ohnson et al., 1982; Dennel et al., 2006).

The upper borderline of Pinjor stage is normally placed in the Early Middle Pleistocene, ca 0.6 My. All through this period, deposition was mostly seasonal, periodic and fine grained (Keller et al., 1977; Raynold and Johnson, 1985).

Tatrot and Kotal Kund (Lat. $32^{\circ} 46^{\prime} 0^{\prime \prime}$ N, Long. $73^{\circ}$ $18^{\prime} 0$ " E) belong to Tatrot Formation The fossiliferous deposits of the Tatrot Formation outcropping in the area consist of pale pinkish orange brown clays, brownish grey fine to medium grained sandstones intercalated with dark grey conglomerates. Hussain et al (1992) and Barry et al (2002) dated the lower boundary of the Tatrot Formation between 3.5-3.3 or 3.4-3.2 My wherease Kumaravel et al 
(2005), Dennel et al. (2008) and Nanda (2008) dated the upper boundary of the Tatrot Formation between 2.4-2.6 My. Thus Tatrot Formation roughly corresponds to the latest Pliocene.

\section{MATERIALS AND METHODS}

The material found, comprised of isolated molars of Hippohyus sivalensis from Upper Siwaliks, Pakistan. Determination at species level can be attempted by comparison with the material described by Pickford (1988). The specimens were collected simply by surface collection method during the various field work by the authors. The fossils are housed in the Abu Bakr Fossil Display and Research Center of the Department of Zoology, University of the Punjab, Lahore, Pakistan. The specimens catalogue in two series i.e. serial catalogue number and the year. The upper figure denotes the collection year, while the lower one denotes the serial number of the respective specimen. Measurements of the specimens are given in millimeters, and taken with the help of metric Vernier Calipers.

\section{RESULTS AND DISCUSSION}

Family: Suidae Gray, 1821

Subfamily: Suinae Zittel, 1893

Genus: Hippohyus sivalensis Falconer and Cautley in Owen 1840-45

\section{Generic diagnosis}

Suinae with hypsodont cheek teeth, without cement cover, short snout with relatively vertically implanted incisors. Parietal crests close together but not joined to form a saggittal crest. Molar and premolar enamel thin; furchen deep, forming complex infolding of enamel surfaces. No labial pillar in lower molars. Orbits and zygomatic arches situated further forwards than in Propotamochoerus. P3 with two labial main cusps and two ridges leading from labial cusp tips down lingual surface onto lingual cingulum (Pickford, 1988).

\section{Geographic distribution}

Hippohyus has only been recorded from Pakistan (Tatrot, Hasnot, Kotal Kund, Phta, Kolsa, Darapur, Jabi, Kakrala) and India (Pinjor) in a very Late Miocene to Pliocene sediments (ca. 5-2 Ma) (Pickford, 1988).

\section{Hippohyus sivalensis Falconer and Cautley}

\section{Synonym list}

1840-45 Hippohyus sivalensis gen. et. Sp. nov. Falconer and Cautley, in Owen, Sus (Hippohyus) sivalensis
(F and C) Falconer, 1879 Hippohyus F and C. Lydekker, Hippohyus grandis sp. nov. Pilgrim.

\section{Specific diagnosis}

A species of Hippohyus of large size with upper molar row longer than $65 \mathrm{~mm}$.

PI. CXL.

Holotype: Specimen illustrated in Owen, (1840-45)

Horizon: Upper Siwaliks and Middle Siwaliks.

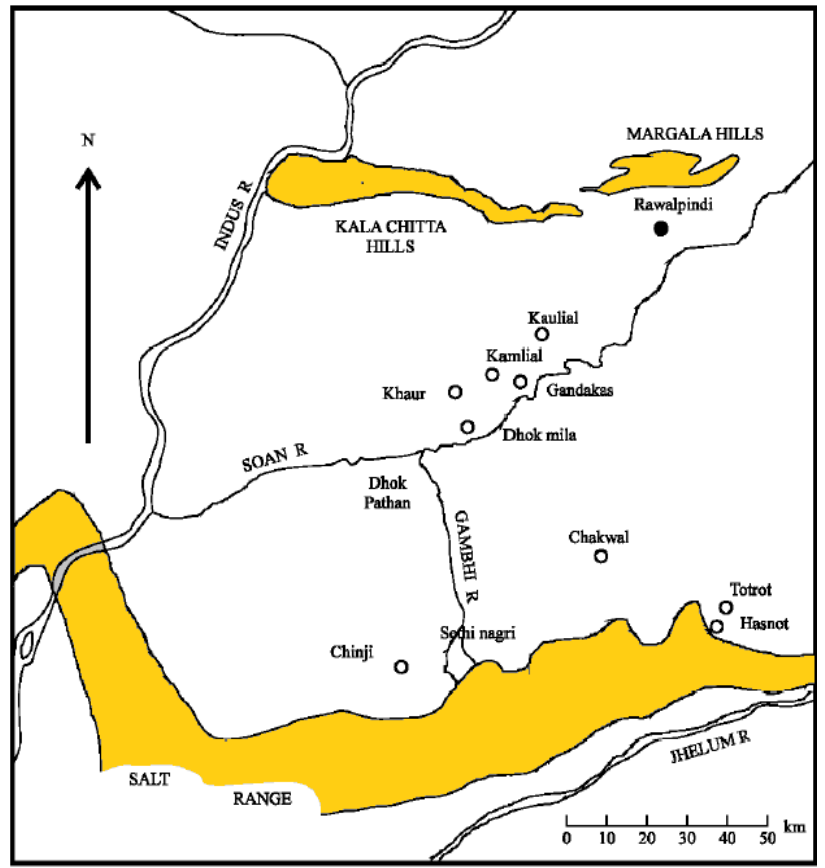

Fig. 1. Map of the study section showing main fossil localities.

\section{Studied material}

Upper dentition

1. PUPC 97/89 (Fig. 3, Table I), an isolated broken upper right third molar, collected from Tatrot, district Jhelum, Punjab province, Pakistan.

2. PUPC $15 / 39$ (Fig. 2, Table I), an isolated upper left first molar, collected from Pinjor, district Jhelum, Punjab province, Pakistan.

3. PUPC $15 / 350$ (Fig. 2, Table I), an isolated upper left third molar, collected from Hasnot, district Jhelum, Punjab province, Pakistan (Fig. 5).

4. PUPC $15 / 21$ (Fig. 3, Table I), an isolated upper left second molar, collected from Kotal Kund, district Jhelum, Punjab province, Pakistan (Fig. 5).

5. PUPC 15/356 (Fig. 2, Table I), an isolated upper left first molar, collected from Hasnot, district Jhelum, Punjab province, Pakistan (Fig. 5). 
Table I. Hippohyus sivalensis (*Referred data taken from Pickford, 1988; Batool et al., 2015).

\begin{tabular}{|c|c|c|c|c|c|}
\hline Specimen & $\begin{array}{l}\text { Posi- } \\
\text { tion }\end{array}$ & $\begin{array}{l}\text { Length } \\
(\mathrm{mm})\end{array}$ & $\begin{array}{l}\text { Width } \\
\text { (mm) }\end{array}$ & $\begin{array}{l}\text { Height } \\
(\mathbf{m m})\end{array}$ & $\begin{array}{l}W / L \\
\text { index }\end{array}$ \\
\hline PUPC 97/89 & rM3 & $25.7+$ & 16.4 & 14.2 & 0.63 \\
\hline PUPC 15/39 & 1M1 & 20.2 & 18.0 & 8.7 & 0.89 \\
\hline PUPC 15/350 & 1M3 & 34.1 & 19.8 & 10.0 & 0.58 \\
\hline PUPC 15/21 & $1 \mathrm{M} 2$ & 26.6 & 21.2 & 12.9 & 0.79 \\
\hline PUPC 15/356 & 1M1 & 20.7 & 17.7 & 10.0 & 0.85 \\
\hline PUPC 16/92 & $\mathrm{rm} 1$ & 18.0 & 13.1 & 10.1 & 0.72 \\
\hline *B66 & M3 & 35 & 22.7 & - & 0.64 \\
\hline *K33 & M3 & 33.5 & 21.4 & - & 0.63 \\
\hline *B720 & M3 & 38 & 24.5 & - & 0.64 \\
\hline *B722 & M1 & 17.5 & 16.6 & - & 0.94 \\
\hline$* \mathrm{~K} / 601$ & M1 & 22.6 & 17.6 & - & 0.77 \\
\hline *B722 & M2 & 28 & 21.5 & - & 0.76 \\
\hline$*_{\mathrm{K}} 15 / 914$ & M2 & 24.6 & 19.8 & - & 0.80 \\
\hline *K13/922 & M2 & 24.3 & 21 & - & 0.86 \\
\hline$* \mathrm{~B} 721$ & $\mathrm{~m} 1$ & 20 & 12 & - & 0.6 \\
\hline *PC-GCUF 12/48 & 1M2 & 23.4 & 19.0 & - & 0.81 \\
\hline *PC-GCUF 12/22 & $1 \mathrm{M} 3$ & 32.1 & 20.4 & - & 0.63 \\
\hline
\end{tabular}

$1 \mathrm{a}$

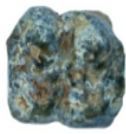

$2 a$

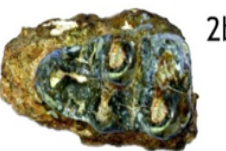

$2 b$
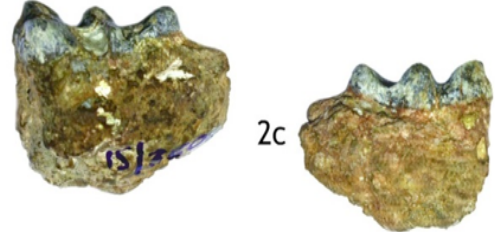

3a

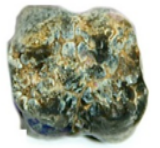

$2 c$

$1 \mathrm{~b}$

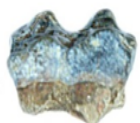

$1 \mathrm{c}$

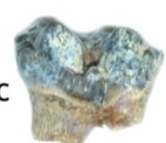

$3 b$

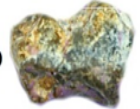

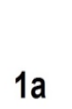

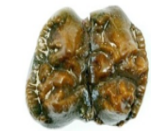

$1 b$

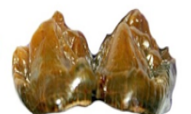

1c

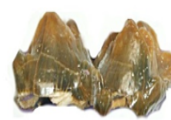

$2 a$

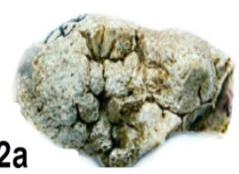

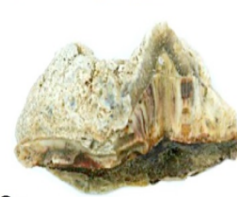

2c
Fig. 3. Hippohyus sivalensis. Upper dDentition: 1, PUPC 15/21, 1M2; 2, PUPC 97/89, rM3; a, occlusal view; b, lingual view; c, buccal view; scale bar, $10 \mathrm{~mm}$.
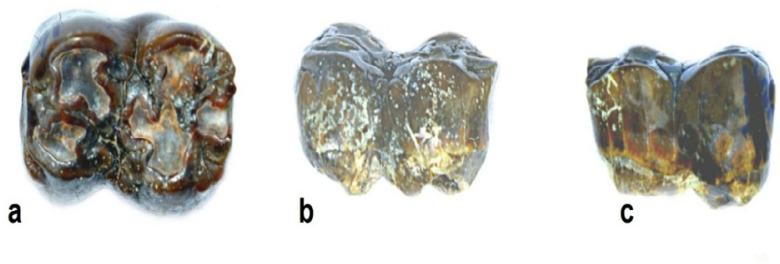

Fig. 4. Hippohyus sivalensis. 1. lower dentition: pupc 16/92 rm1; a, occlusal view; b, lingual view; c, buccal view. Scale bar, $10 \mathrm{~mm}$.
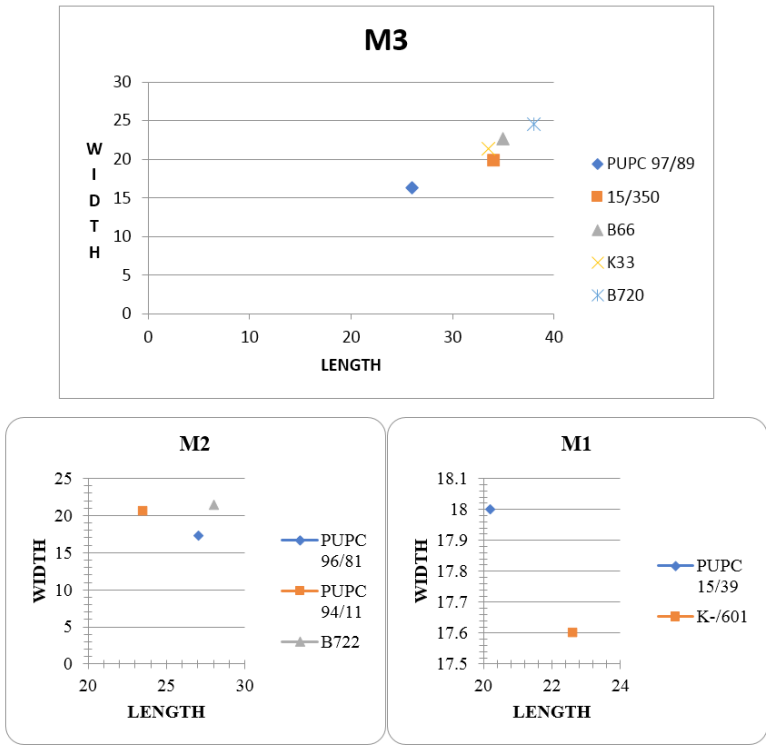

Fig. 2. Hippohyus sivalensis. Upper dentition: 1, PUPC 15/39, 1M1; 2, PUPC 15/350, 1M3; 3, PUPC 15/356, lM1; a, occlusal view; b, lingual view; c, buccal view; scale bar, $10 \mathrm{~mm}$.

\section{Lower dentition}

PUPC 16/92 (Fig. 4, Table I), an isolated lower right first molar collected from Tatrot, district Jhelum, Punjab province, Pakistan (Fig. 5).
Fig. 5. Scatter diagrams of cheek teeth of Hippohyus sivalensis. Comparative measurements have been taken from Pickford 1988.

Stratigraphic and geographic distribution of the present material

Kotal Kund, Tatrot, Hasnot, Pinjor. Upper Siwaliks; Late Miocene to Pliocene. 


\section{Description}

Upper dentition

Upper first molar (PUPC 15/39, Fig. 2, Table I) consists of four main blunt cusps. Thick flare of cingulum is present. Median accessory cusp is present in the median valley. Median basal pillar is present at the end of median valley on one side. Enamel is thick. Main cusps are characterized by three furchen leading into sagittal valley anteriorly and posteriorly.

Upper second molar (PUPC 15/21, Fig. 2, Table I) consists of four main cusps. Anterior, posterior and median accessory cusps are prominent along with anterior and posterior cingulum. A marked feature of the molar is the considerable mesiodistal undercut in the molar, so that the crown is considerably longer at the tip than it is at the cervix. The median valley is broad having broader medium accessory cusp. Median basal pillar present lingually and labially at the end of median valley.

Upper third molar (PUPC 97/89, Fig. 3, Table I) is 4 cusped tooth with talon. Small portion of anterior cusps are broken. Median accessory cusp is visible. Enamel is rugose. PUPC 15/350 (Fig. 2) is large tooth with 4 main cusps (Table I). Anterior and posterior cusps are lophodont. Paracone is broken. Tooth is in middle stage of wear. Dentine is visible on top. Thin layer of cingulum is present anteriorly and posteriorly it expands to form broad talon. No accessory cusps are visible. Talon is marked laterally by cingular cusplets.

\section{Lower dentition}

Lower first molar (PUPC 16/92, Fig. 4, Table I) is four cusped tooth. It contains main features of genus Hippohyus. Median accessory cusp is present in the median valley. Median basal pillar is present. Moderately thick enamel is present. Thick flare of cingulum surrounds the tooth.

\section{Comparison and discussion}

Specimens have been assigned to $H$. sivalensis due to thin enamel, deep furchen, basic outline of the molar and complex infolding of enamel surfaces.

Pilgrim (1926) described Hippohyus sivalensis based upon complete skull. It has never been recorded from the Nagri and Dhok Pathan formations, but is common in Tatrot /Hasnot areas. It is a late Miocene to Pliocene form. It is often found with Sivahyus, Sivachoerus, and Sus, and occasionally with large from of Hippopotamodon sivalensis.

The skull morphology was similar to that of Propotamochoerus with some differences. The front half of the skull of Hippohyus is shorter than that of Propotamochoerus because its snout is remarkably shortened and no diastema is present. However, the dentition of Hippohyus is different from that of Propotamochoerus. Crown of the upper incisors and canine are little known. The cheek teeth are better known and comparatively higher crowned than those of $P$. hysudricus. First and second upper premolars are poorly known. Third upper premolar consists of single main cusp along with anterior and posterior accessory cusps. The ridges of lingual cingulum are different from those of Propotamochoerus. $\mathrm{P} 4$ is much more similar to that of Propotamochoerus, with two main labial cusps, a lingual main cusp, two sagittal cusplets and anterior and posterior cingula. Molars are also homologous to those of Propotamochoerus. Enamel thickness of Hippohyus and Propotamochoerus is also comparable. The molars consist of four main cusps, anterior, median and posterior cingula. No basal pillars are present; however, in Propotamochoerus variable basal pillars are present on labial side of median valley in Sivahyus. Last molar has relatively simple and hypsodont talon. Thus, Hippohyus differs from Propotamochoerus by having shortened snout, vertical incisors and relatively hypsodont molars instead of long snout, procumbent incisors and low crowned molars with shallow furchen in Propotamochoerus. These differences might reflect evolution due to diet modification. Superficially Hippohyus molars resemble Equus molars and this might be due to their comparable foods. The presence of deep furchen in molars effectively increases the length of cutting edge. Thus, it is postulated that Hippohyus was probably grazer rather than browser or omnivore. Thus, it is suggested that Hippohyus evolved after the grass cover become significant.

Hippohyus sivalensis differs from Hippohyus lydekkeri mainly in size and hypsodonty. There is also difference of canine morphology due to sexual dimorphism. H. sivalensis is greater than $H$. lydekkeri but there are few specimens of $H$. lydekkeri that have the size of $H$. sivalensis. H. lydekkeri is less hypsodont as compare to $H$. sivalensis so it is reliable criteria to separate the two species of Hippohyus. The mandible of $H$. sivalensis is suine except in shortening of the symphysis and implantation of the incisive battery is more vertical (Lydekker, 1884). Moreover, H. lydekkeri is Pliocene species. This work supports the work of Pickford on Hippohyus.

\section{CONCLUSION}

Hippohyus sivalensis is a late Miocene to Pliocene suid found in Middle and Upper Siwaliks. It is grazing species of suids adapted to grassland habitat. This study will help to understand origin and dispersal of Siwalik Late Miocene to Pliocene suids. 
Statement of conflict of interest

The authors have declared no conflict of interest.

\section{REFERENCES}

Barry, J., Morgan, M., Flynn, L., Pilbeam, D., Behrensmeyer, A. K., Raza, S., Khan, I., Badgely, C., Hicks, J. and Kelley, J., 2002. Faunal and environmental change in the Late Miocene Siwaliks of Northern Pakistan. Paleobiol. Mem., 28: 1-72. https://doi.org/10.1666/00948373(2002)28[1:FAECIT]2.0.CO;2

Batool, A., Khan, M.A. and Qureshi, N.A., 2015. New fossils of Suidae (Mammalia, Artiodactyla) from the Hasnot Late Miocene, Northern Pakistan. J. Anim. Pl. Sci., 25: 578-590. https://doi.org/10.1016/j. palwor.2015.10.002

Colbert, E.H., 1935. Siwalik mammals in the American Museum of Natural History. Trans. Am. Phil. Soc., N.S., 26: 1-401. https://doi.org/10.2307/1005467

Dennel, R., Coard, R. and Turner A., 2006. The biostratigraphy and magnetic polarity zonation of the Pabbi Hills, northern Pakistan: An upper siwalik pinjor stage upper pliocene-lower pleistocene fluvial sequence. Palaeogeogr. Palaeoclimatol. Palaeoecol., 234: 168-185. https:// doi.org/10.1016/j.palaeo.2005.10.008

Dennell, R.W., Coard, R. and Turner, A., 2008. Predators and scavengers in early pleistocene southern Asia. Quart. Int., 192: 78-88. https://doi.org/10.1016/j. quaint.2007.06.023

Hussain, S.T., Van-Den-Bergh, G.D., Steensma, K.J., De Visser, J.A., Devos, J., Arif, M., Van Dam, J., Sondaar, P.Y. and Malik, S.M., 1992. Biostratigraphy of the pliopleistocene continental sediments Upper Siwalik Pilgrims of the ManglaSamwal anticline, Azad Kashmir, Pakistan. Proc. Konink. Nederl. Akad. Wetensch. Ser. B. 95: 65-80.

Johnson, N.M., Opdyke, N.D., Johnson, G.D., Lindsay, E.H. and Tahirkheli, R.A.K., 1982. Magnetic polarity stratigraphy and ages of Siwalik Group rocks of the Potwar Plateau, Pakistan. Palaeogeogr. Palaeoclimatol. Palaeoecol., 37: 17-42. https:// doi.org/10.1016/0031-0182(82)90056-6

Keller, H.M.R., Tahirkheli, A.K., Mirza, M.A., Johnson, G.D., Johnson, N.M. and Opdyke, N.D., 1977. Magnetic polarity stratigraphy of the Upper Siwalik deposits, Pabbi Hills, Pakistan. Earth Planet. Sci. Lett., 36: 187-201. https://doi.org/10.1016/0012821X(77)90198-4

Kumaravel, V., Sangode, S.J., Kumar, R. and Siva Siddaiah, N., 2005. Magnetic polarity stratigraphy of Plio-Pleistocene Pinjor formation (type locality), Siwalik group, NW Himalaya, India. Curr. Sci., 88: 1453-1461.

Lewis, G.E., 1934. Preliminary notice of a new manlike ape from India. Am. J. Sci., 27: 161-181. https://doi.org/10.2475/ajs.s5-27.159.161

Lydekker, R. 1884. Indian tertiary and post-tertiary vertebrata Siwalik and Narbada Bunodont Suina. Mem. Geol. Surv. India. Palaeont. Indica., 3: 35104.

Matthew, W.D., 1929. Critical observation upon Siwalik mammals. Bull. Am. Mus. Nat. Hist., 56: 435-560.

Medlicott, H.B., 1864. On the geological structure and relations of the Southern portion of the Himalayan range between the Rivers Ganges and Ravi. Geol. Surv. India, Mem. III.

Nanda, A.C., 2008. Comments on the pinjor mammalian fauna of the siwalik group in relation to the postsiwalik faunas of peninsular India and indogangetic plain. Quart. Int., 192: 6-13. https://doi. org/10.1016/j.quaint.2007.06.022

Pickford, M., 1988. Revision of the Miocene Suidae of the Indian Subcontinent. Munchner Geowissensch. Abhandl. Reihe A, Geol. Palaontol., 12: 1-92.

Pickford, M., 1993. Old world suoid systematics, phylogeny, biogeography and biostratigraphy. Paleontol. I. Evol., 26: 237-269.

Pilgrim, G.E., 1926. The fossil Suidae of India. Memoirs of the Geological Survey of India. Palaeontol. Indica New Ser., 8: 1-105.

Raynold, R.G.H. and Johnson, G.D., 1985. Rates of Neogene depositional and deformational processes, North west Himalayan foresddep margin, Pakistan. In: The chronology of the geological record (ed. N.J. Snelling). Geology Society, London. pp. 297-311. https://doi. org/10.1144/GSL.MEM.1985.010.01.24

Sarwar, H.M.A., Waseem, M.T., Khan, A.M. and Ahmed, R.M., 2016. Propotamochoerus hysudricus remains from late Miocene deposits of Hasnot Pakistan. Punjab Univ. J. Zool., 31: 243-248. 